\title{
SponDT (Spondylodiscitis Diagnosis and Treatment): spondylodiscitis scoring system
}

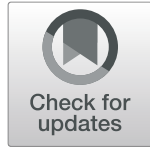

\author{
Lars Homagk ${ }^{1,4^{*}}$ (D), Daniel Marmelstein ${ }^{2}$, Nadine Homagk ${ }^{2}$ and Gunther O. Hofmann ${ }^{3}$
}

\begin{abstract}
Background: Spondylodiscitis is a chameleon among infectious diseases due to the lack of specific symptoms with which it is associated. It is nevertheless a serious infection, with $7 \%$ mortality of hospitalized patients, in large part because of delayed diagnosis. The aim of this study was to develop a diagnosis and course-of-disease index to optimize its treatment.

Material and methods: Through analysis of 296 patients between January 1998 and December 2013, we developed a scoring system for spondylodiscitis, which we term SponDT (Spondylodiscitis Diagnosis and Treatment) based on three traits: (1) the inflammatory marker C-reactive protein (CRP) ( $\mathrm{mg} / \mathrm{dll})$, (2) pain according to a numeric rating scale (NRS) and (3) magnetic resonance imaging (MRI), to monitor its progression following treatment.

Results: The number of patients receiving treatment increased over the past 15 years of our study. We also found an increasing age of patients at the point of diagnosis across the study, with an average age of 67.7 years. In $34 \%$ of patients, spondylodiscitis developed spontaneously. Almost $70 \%$ of them did not receive treatment until the first diagnosis using SponDT. Following treatment against spondylodiscitis, pain intensity decreased from 6.0 to 3.1 NRS. The inflammatory markers also decreased (CRP from 119.2 to $46.7 \mathrm{mg} / \mathrm{dl}$ ). Similarly, MRI revealed a regression in inflammation following treatment. By employing SponDT, patients were diagnosed and entered into treatment with a score of 5.6 (severe spondylodiscitis) and discharged with a score of 2.4 (light/healed spondylodiscitis).
\end{abstract}

Conclusion: SponDT can be used to support the diagnosis of spondylodiscitis, particularly in patients suffering from back pain and elevated levels of inflammation, and can be used during the course of treatment to optimize control of therapy.

Level of evidence: lla —evidence from at least one well-designed controlled trial which is not randomized

Keywords: Spondylodiscitis, Scoring system, Classification of severity

\section{Introduction}

Spondylodiscitis is an infectious inflammation that affects the vertebrae, vertebral discs and adjacent structures. It may have a bacterial or non-bacterial aetiology, and, in the former case, a relatively broad spectrum of pathogens is considered to induce spondylodiscitis; the largest proportion of spondylodiscitis cases is caused by Staphylococcus aureus [1-3]. The incidence of spondylodiscitis is on average seven per million, with men three times more frequently affected than women. Although spondylodiscitis is

\footnotetext{
* Correspondence: info@praxisklinik-dr-homagk.de

${ }^{1}$ Praxisklinik Dr. Homagk - MVZ GmbH, 06667 Weißenfels, Germany

${ }^{4}$ Praxisklinik Dr. Homagk, Markt 3, 06618 Naumburg, Germany

Full list of author information is available at the end of the article
}

a rare disease, the widespread use of drugs that suppress the immune system and an ageing population have led to an increase in cases of infection [3, 4]. Though the disease is most often seen in the sixth decade of life, it can occur at any age. In addition to age, risk factors include diabetes mellitus, malnutrition and disorders inducing a loss of weight, steroid therapy, rheumatic diseases and spinal surgery. Often, the actual source of infection is no longer detectable at diagnosis [5-7].

Before the use of antibiotics, spondylodiscitis thought to have led to mortality of $25-71 \%$ of cases. The rate of mortality lies at $2-12 \%[2,3,8]$. Pathogenesis is through blood-borne transport of pathogens following surgical intervention or following growth of a soft tissue

(C) The Author(s). 2019 Open Access This article is distributed under the terms of the Creative Commons Attribution 4.0 International License (http://creativecommons.org/licenses/by/4.0/), which permits unrestricted use, distribution, and 
infection. Spontaneous spondylodiscitis also occurs via a haematogenous route [9-11]. The number of cases of spondylodiscitis arising from a post-operative infection is less than those arising from blood-borne infections. The most common site of spondylodiscitis is the lumbar spine $(60 \%)$, followed by the breast $(30 \%)$ and the cervical spine $(10 \%)[3,5,7]$.

Spondylodiscitis can characterize in its early stages by rather nonspecific clinical symptoms such as mild fever, general malaise, weakness and weight loss. Because of the lack of specificity of the symptoms, there is often a delay of several weeks and up to 6 months in its diagnosis $[2,3,9,12]$. The disease can also be associated with acute sepsis, multiorgan failure and neurological symptoms. These may be due to a para- or intraspinal abscess or destruction of bony parts of vertebrae. The mortality of acute spondylodiscitis cases can rise to $17 \%[2,3]$.

In addition to neurological examination in the clinic, early diagnostic parameters of spondylodiscitis include elevated body temperature, increased C-reactive protein (CRP) titres and an increased white blood cell count. A serious limitation in diagnosis is that these parameters, though having high specificity for the detection of an infection, have only low sensitivity for the detection of spondylodiscitis $[13,14]$. Therefore, a further prerequisite for adequate treatment of spondylodiscitis beyond early detection is an accurate diagnosis, which can often only be determined by histological analysis or direct detection of causative pathogens. One route of pathogen detection is via culturing of blood or the cultivation of pathogens from biopsy material $[1,15,16]$.

Culturing of blood is the easiest, cheapest and most effective method for confirming the presence of a pathogen. Since haematogenous spondylodiscitis is usually caused by a single pathogen [17], there is a high probability of detecting it via culturing of blood, for which both aerobic and anaerobic blood cultures should be employed. Pathogens could be detected in $40-70 \%$ of patients who had not been treated with antibiotics $[15,18]$. Up to $82 \%$ of spondylodiscitis cases with an epidural abscess have pathogens detectable in the blood [19].

X-ray images of spinal segments affected by spondylodiscitis occasionally exhibit primary non-specific changes associated with osteolysis and shadowing of the paravertebral soft tissue, suggestive of a spinal abscess. MRI is more sensitive and specific for the diagnosis of spondylodiscitis and therefore the method of choice [11, 20]. If MRI does not allow diagnosis when spondylodiscitis is suspected, it is then important to undertake a computer tomography $(\mathrm{CT})$ in conjunction with a contrast medium (edge enhancement of the paravertebral abscesses) for the assessment of the stability of bony structures. Scintigraphy is of low diagnostic specificity and sensitivity but might help in following the course of infection. Image intensification or CT scan-based puncturing for pathogen detection can be performed transpedicular or extrapedicular but is only successful in about $50 \%$ of the cases; it is only recommended where conservative therapy is sought $[11,12]$.

Spinal cord or nerve root compression with abscesses, destructive lesions that lead to bony spinal instability, and other abscesses should be treated surgically $[8,21]$. The aim of the surgery is to achieve a radical and complete elimination of any inflamed or necrotic tissue, to clean the site of infection and to restore the stability of the spine. A variety of materials can be used to stabilize the spine, depending on the size of the damaged area to be cleaned, e.g. mono- or bicortical pelvic chips, fibulainterponate or, now more rarely, cortico-tibial chips as well as implants such as titanium cages [3, 22]. Increasingly, a minimally invasive surgical procedure is advised [5, 21, 22].

Considering the difficulty in diagnosis of the disease, the aim of this study was to develop a tool to control the treatment of spondylodiscitis.

\section{Material and methods}

In this retrospective study, we took into consideration all cases of spondylodiscitis (total 296 patients) from January 1998 through to December 2013. We collected their medical history, associated pathogens, location of spondylodiscitis, time spent in hospital, number of operations, age, pre-admittance treatment, possible causes of illness and non-radiological diagnosis (clinical, laboratory, microbiology). We assessed their C-reactive protein (CRP) levels in addition to the usual routine chemical laboratory diagnostics: blood count, coagulation, electrolytes, liver enzymes, kidney enzymes and urine. To confirm the diagnosis of spondylodiscitis and exclude other causes, we evaluated original radiographs; computed tomography images, possibly with aspiration (CT); and magnetic resonance imaging (MRI).

From the in-house electronic medical records, we generated a measure of the pain intensity of patients using a numerical rating scale (NRS), which ranged from 0 (lowest pain intensity) to 10 (highest pain intensity). The NRS was based on interviews with patients and additional daily recording of pain intensity, as expressed by the patient at rest, though changes in the treatment for pain and through patient mobility [23].

As part of the pre-operative evaluation, the general condition of the patient by the anaesthetist was recorded using the American Society of Asesthesiologists (ASA) classification. This scheme, proposed in 1940 by the American Society of Anesthesiologists, is 
widely used in medicine for classifying patients into groups with respect to their physical condition. It distinguishes patients before anaesthesia on the basis of their systemic illnesses [24, 25].

\section{Results and discussion}

The 296 patients included in our study had a mean age of 67.3 years. $66.2 \%$ were 60 to 80 years old and $56.7 \%$ were male. In $34.3 \%$ of patients, the cause of spondylodiscitis could not be determined. The most common known causes were medical interventional measures (e.g. infiltration, a spine operation or another operation; 36.2\%), followed by previous sepsis (14.3\%) or vertebral fracture (7.5\%). Figure 1 gives other causes of spondylodiscitis.

ASA classification placed $>66 \%$ of patients in stages III and IV at first diagnosis. There was no significant change over the course of the study. Diabetes mellitus was recorded in a total of $42.2 \%$ of patients, $26.2 \%$ of whom were already receiving treatment with insulin (Fig. 2).

Patients were generally in a reduced state of health when first diagnosed with spondylodiscitis, which is reflected in their poor routine chemical laboratory diagnostics. In addition, their C-reactive protein (CRP) level was $119.2 \mathrm{mg} / \mathrm{dl}$, well above the standard value of $<10$ $\mathrm{mg} / \mathrm{dl}$, though it fell to $46.7 \mathrm{mg} / \mathrm{dl}$ following surgery and antibiotic treatment (Fig. 3).

Leukocyte levels of spondylodiscitis patients at first diagnosis were $10.6 \mathrm{Gpt} / \mathrm{l}$, not significantly higher than the normal value of $9.5 \mathrm{Gpt} / \mathrm{l}$. They generally fell across the course of treatment for spondylodiscitis to the normal value of 9.5 on discharge, though they exhibited a transient rise at week 4 after initiation of treatment. The subjective perception of patient pain decreased significantly from 6.0 NRS to 3.1 NRS following diagnosis and treatment for spondylodiscitis (Fig. 4).

On admission, all 296 patients received imaging, of which $64 \%$ were conventionally $x$-rayed and $78 \%$ involved CT examination. MRI was performed on $74 \%$ of all patients. With the introduction of SponDT in our daily procedure in 2004, every patient received MR imaging. Only exceptions are a pacemaker or really bad condition of patients. This MRI was followed by morphological classification of patients, following Flamme et al. [20] (see Table 1).

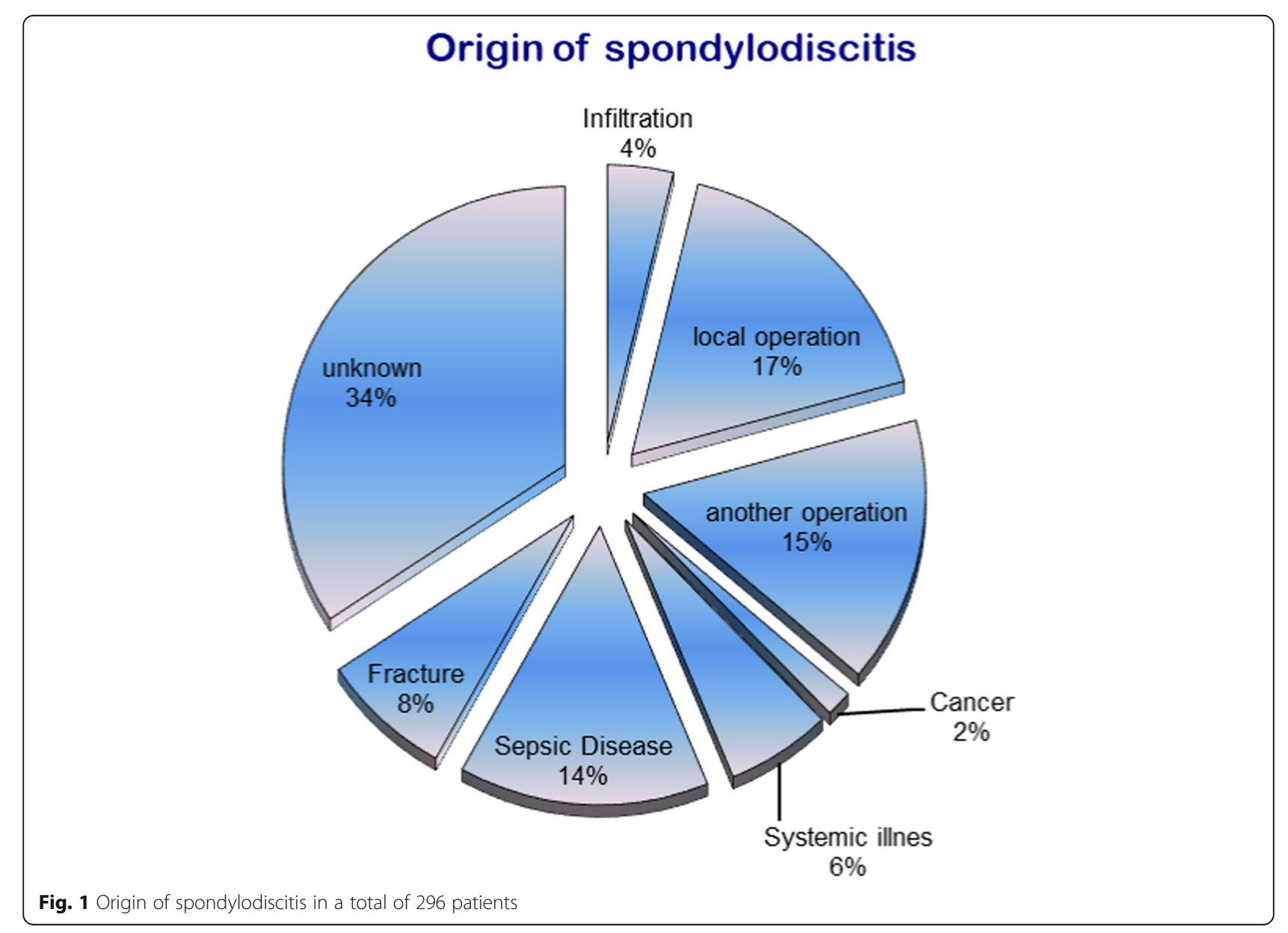




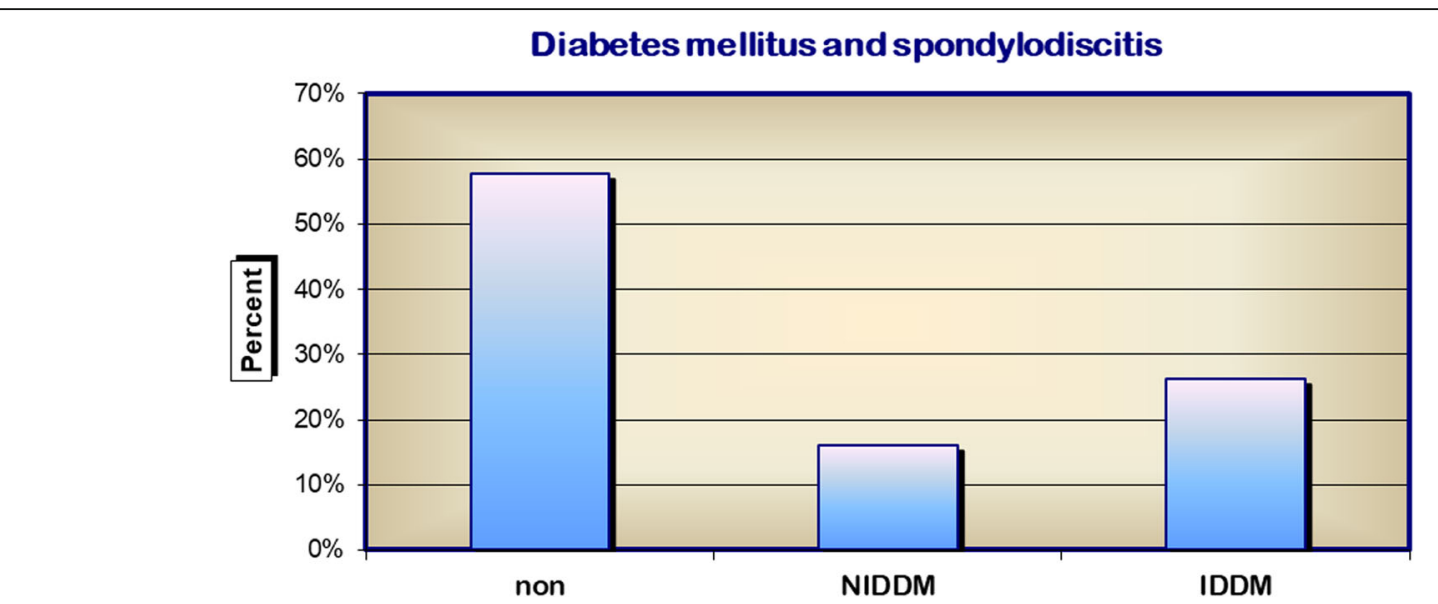

Fig. 2 Diabetes mellitus and spondylodiscitis. NIDDM non-insulin dependent diabetes mellitus, IDDM insulin dependent diabetes mellitus

In MRI follow-up imaging, it was found that spondylodiscitis could not be detected in $6.1 \%$ of patients studied. Paravertebral abscesses were also significantly reduced in prevalence from an initial $33.7 \%$ of patients to $12.1 \%$ of patients (Fig. 5).

Based on these data, we developed a spondylodiscitis diagnosis and treatment score, in short SponDT (Table 2), to be used as a treatment monitoring tool.

According to the score value, following the grade of severity could be performed (Table 3):

This classification of severity of spondylodiscitis was made on the basis of SponDT. It showed that $21 \%$ of patient's initially had severe spondylodiscitis and $71.6 \%$ a moderate infection with spondylodiscitis. The SponDT score at admission was 5.6. Already in the second week of treatment, the proportion of severe cases of spondylodiscitis was down to $6.3 \%$. The SponDT decreased to 4.4 in the second week and further up to 3.1 in the fourth week or at discharge (Fig. 6). According to that, cases of light spondylodiscitis infection or of healed patients increased from an initial 5.7 to $59.5 \%$. A severe spondylodiscitis in the fourth week was less than $2 \%$.

Spondylodiscitis is a rare illness with non-specific symptoms and is therefore likely to go misdiagnosed. We regularly treat around 20 cases per year. Yet it is also severe, and therefore timely and accurate diagnosis in the outpatient setting is already of immense importance for disease outcome [1,3]. Our data support the view that spondylodiscitis is primarily a disease of old age (60-80-year age group) that more often afflicts men. We were able to show, contrary to the prevailing view, that surgical operations were the main cause of spondylodiscitis [1-3]. Spondylodiscitis was not only associated with spinal surgery but also with other forms of surgery, though other operations inevitably limited the possibilities to diagnose and treat spondylodiscitis, delaying the first diagnosis by 2 months after first symptoms [1, 3].

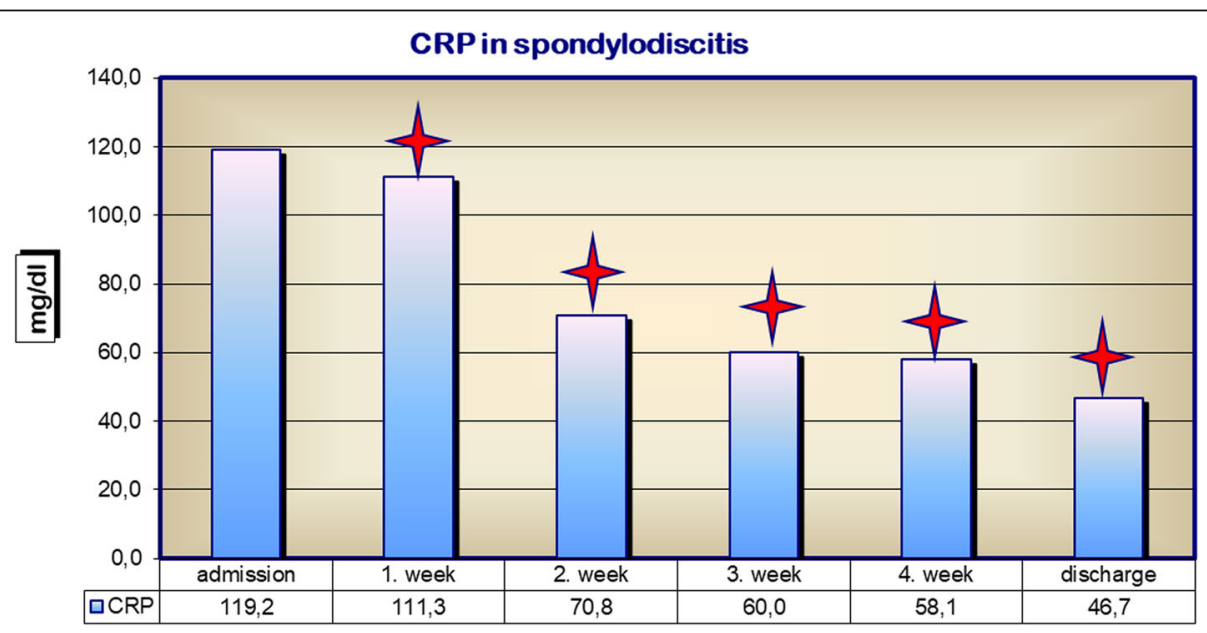

Fig. 3 C-reactive protein (milligrammes per decilitre) on admission and during course of treatment; ${ }^{*} p<0.05$ 


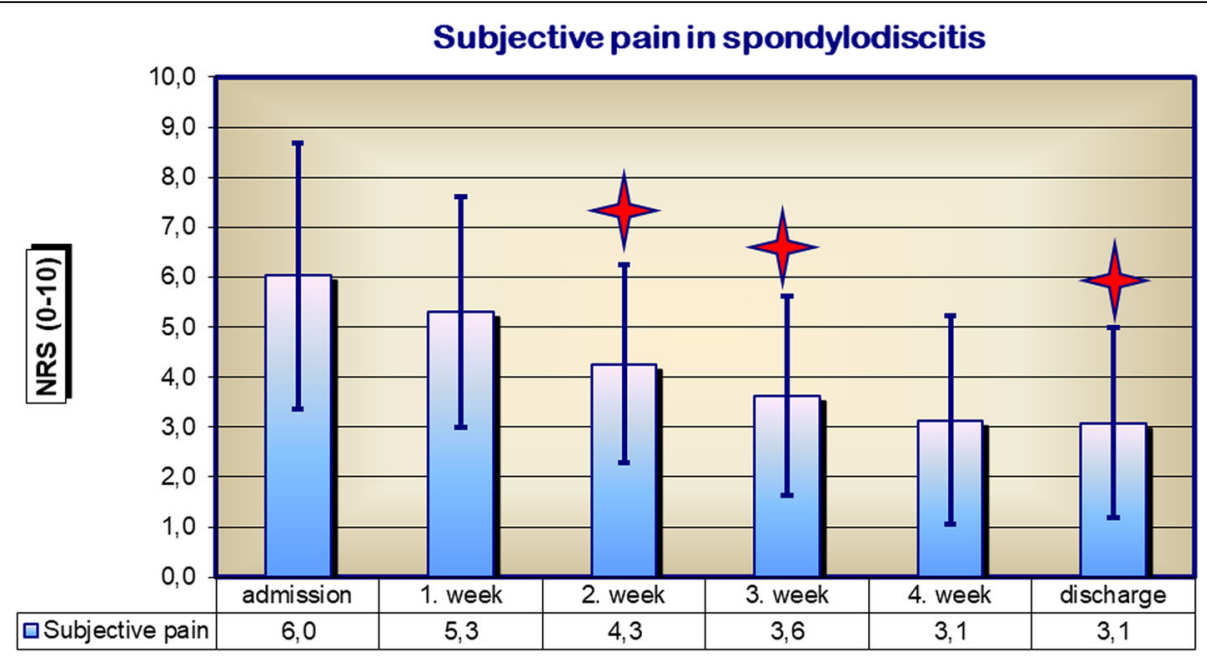

Fig. 4 Subjective perception of pain (NRS) of spondylodiscitis patients on admission and during the course of treatment; ${ }^{*} p<0.05$

Because of the currently poor possibilities to diagnose spondylodiscitis, we set ourselves the goal to optimize treatment of the former. In addition to clinical examination, we propose the use of additional diagnostic parameters for SponDT, namely magnetic resonance imaging [12, 20] and pain assessment of patients with newly arisen back pain or for those whose back pain has lasted several days or that have a reduced general condition. We also recommend laboratory chemical tests of inflammation. These parameters can even be collected from outpatients and fed into SponDT.

MRI shows high sensitivity and specificity for the detection of spondylodiscitis, with over $90 \%$ of cases recognized [12, 20]. Although current data for MRI-based morphological classification of spondylodiscitis is very heterogeneous and not adapted to specific parameters associated with spondylodiscitis, MRI morphological analysis should nevertheless form part of the diagnosis of spondylodiscitis and evaluation of its treatment. Inflammatory markers are also typically elevated in cases of spondylodiscitis. The leukocyte count itself is rather non-specific. An increased CRP has, however, been found to be typical of spondylodiscitis, with a sensitivity of $84 \%$ and a specificity of $71 \%[4,14]$. For this reason, these parameters of SponDT are also used foremost in the treatment control of spondylodiscitis. The rather non-specific pain statement and reduction in general condition, as defined by the ASA classification, in contrast, have great importance in assessing the course of further treatment after initial diagnosis. Therefore, we proposed that the subjective perception of pain by the patient is a valid parameter for assessing the success of treatment [23].

Successful antibiotic treatment of spondylodiscitis decreases inflammation [3, 4, 26]. Our studies also show that there is a parallel reduction in the specific inflammatory parameter CRP following successful treatment. Absolute leukocyte count does not change, illustrating its lack of specificity for the diagnosis of spondylodiscitis [27]. Nevertheless, our studies show that the number of patients with a leukocyte count $>15 \mathrm{Gpt} / \mathrm{l}$ at 4 weeks post treatment was significantly reduced.

We therefore believe that a summary score like SponDT, generated by the parameters CRP, pain and MRI is a useful tool to help diagnose spondylodiscitis and to follow its outcome following treatment. In addition, SponDT allows the severity of spondylodiscitis to be classified.

On admission for spondylodiscitis and during the first week of treatment, our patients had an average SponDT score of 5.6 out of a maximum of 9 points. Of all of our patients, $20 \%$ had severe spondylodiscitis with scores > 6 . This proportion decreased during the course of treatment to less than $2 \%$, suggesting that the treatment was successful. However, the SponDT score of spondylodiscitis patients did not fall following treatment to the ideal value of 0 at discharge, due to lingering pain and persistent findings in the final radiological examination (MRI). We therefore suggest as the goal of spondylodiscitis treatment a SponDT score of less than 3 points. We note

Table 1 MR-based morphological classification staging of spondylodiscitis

\begin{tabular}{lllll}
\hline Stage & 0 & 1 & 2 & 3 \\
\hline MRI & None & $\begin{array}{l}\text { Spondylitis or discitis (T2 intensity, } \\
\text { contrast enhancement) }\end{array}$ & $\begin{array}{l}\text { Spondylodiscitis (T1 intensity, T2, KM intensity, contrast } \\
\text { enhancement in BS/WK, structural disorders) }\end{array}$ & $\begin{array}{l}\text { Spondylodiscitis with a } \\
\text { paravertebral abscess }\end{array}$ \\
\hline
\end{tabular}




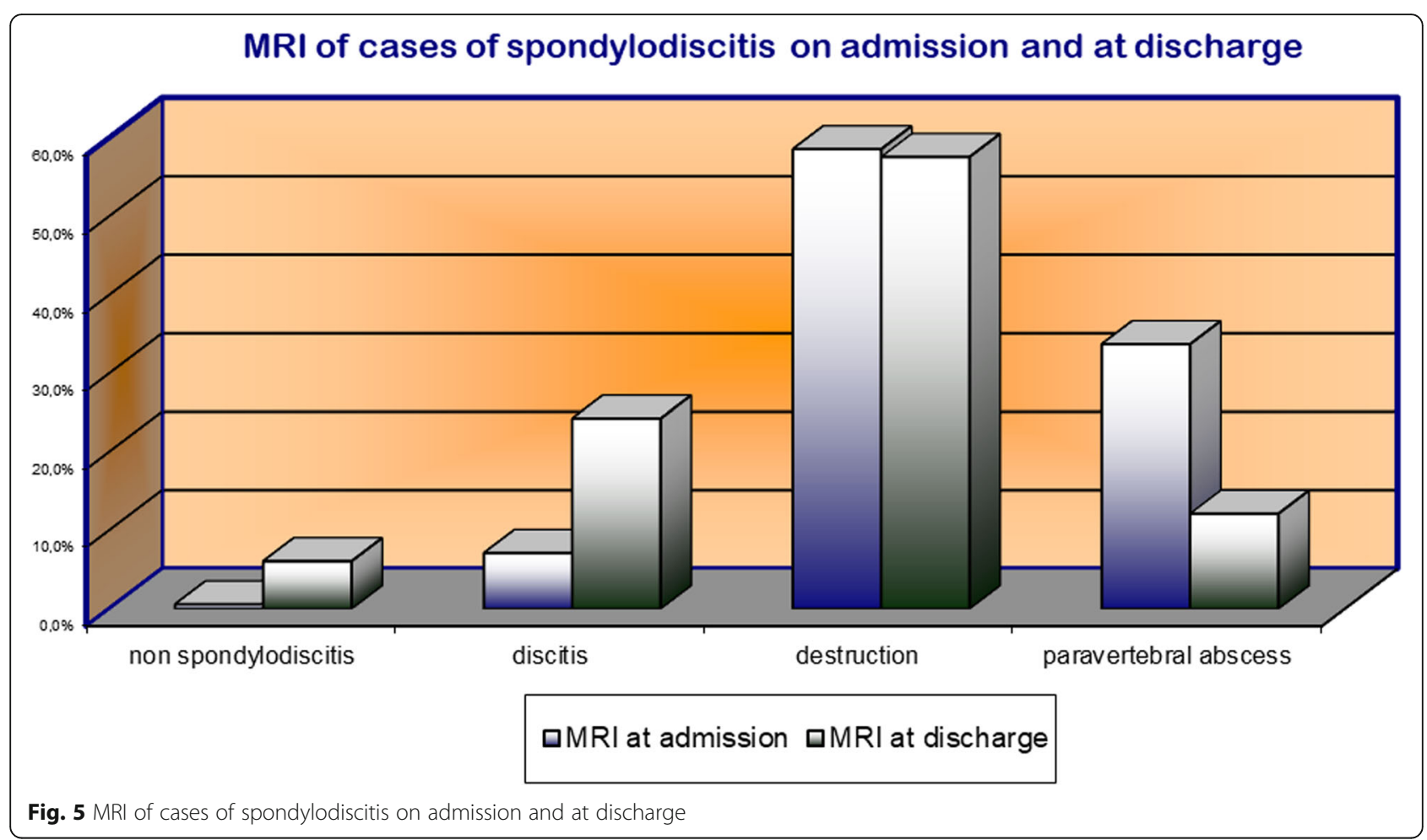

that this means that we cannot draw a distinction between complete remission and a light spondylodiscitis infection. Rather, the purpose of SponDT is to allow individual, patient-based, accurate documentation of the success of treatment. In this context, we see it as justified to incorporate the parameter of pain assessment into SponDT.

In the current literature, spondylodiscitis is associated with a mortality of $2-12 \%[3,28,29]$. We registered a nearly constant rate of mortality of $7 \%$ in our patients, which illustrates the present risk of this disease and the current difficulty in its treatment.

In contrast, our studies suggest that MRI diagnosis cannot be used on its own in monitoring a course of treatment against spondylodiscitis. Though it is an essential component of spondylodiscitis diagnosis $[3,12$, $20]$, it is of lesser value in following disease progression during treatment because it generates artefacts that hinder accurate assessment of disease severity. In addition,

Table 2 Spondylodiscitis scoring system for diagnosis and therapy control using SponDT

\begin{tabular}{lllll}
\hline Score value & 0 & 1 & 2 & 3 \\
\hline CRP (mg/dl) & $<10$ & $11-50$ & $51-150$ & $>150$ \\
Pain (NRS) & $<3$ & $3-5$ & $6-8$ & $>8$ \\
MRI & None/ & Discitis & Spondylodiscitis & $\begin{array}{l}\text { Spondylodiscitis } \\
\text { with abcesses }\end{array}$ \\
& Res & & & \\
\hline
\end{tabular}

the rather specific features that MRI detects in spondylodiscitis patients to not change during the first 2-4 weeks of treatment, apart from possible surgically treated abscesses. Therefore, the main focus of magnetic resonance imaging within SponDT is in the initial assessment of the severity of the disease. Thereafter, during treatment of the disease, levels of inflammatory markers and pain intensity take a more important role in monitoring the progression of spondylodiscitis, independent of the age of the patient.

\section{Conclusion}

In summary, our studies show that the combination of several diagnostic parameters into a single scoring system, SponDT, facilitates the diagnosis of spondylodiscitis. In combination with the spondylodiscitis severity code (SSC), a classification of the severity of spondylodiscitis, SponDT could be established and used for a severity-based treatment. In addition, specific parameters for the treatment of individual grades of severity can be determined in a clinical pathway [30]. Furthermore, the organizing and

Table 3 Classification of the severity of spondylodiscitis using SponDT

\begin{tabular}{ll}
\hline Severity & Point score using SponDT \\
\hline Severe spondylodiscitis & Over 6 \\
Moderate spondylodiscitis & From 3 to 5 \\
Light/healed spondylodiscitis & Under 3 \\
\hline
\end{tabular}




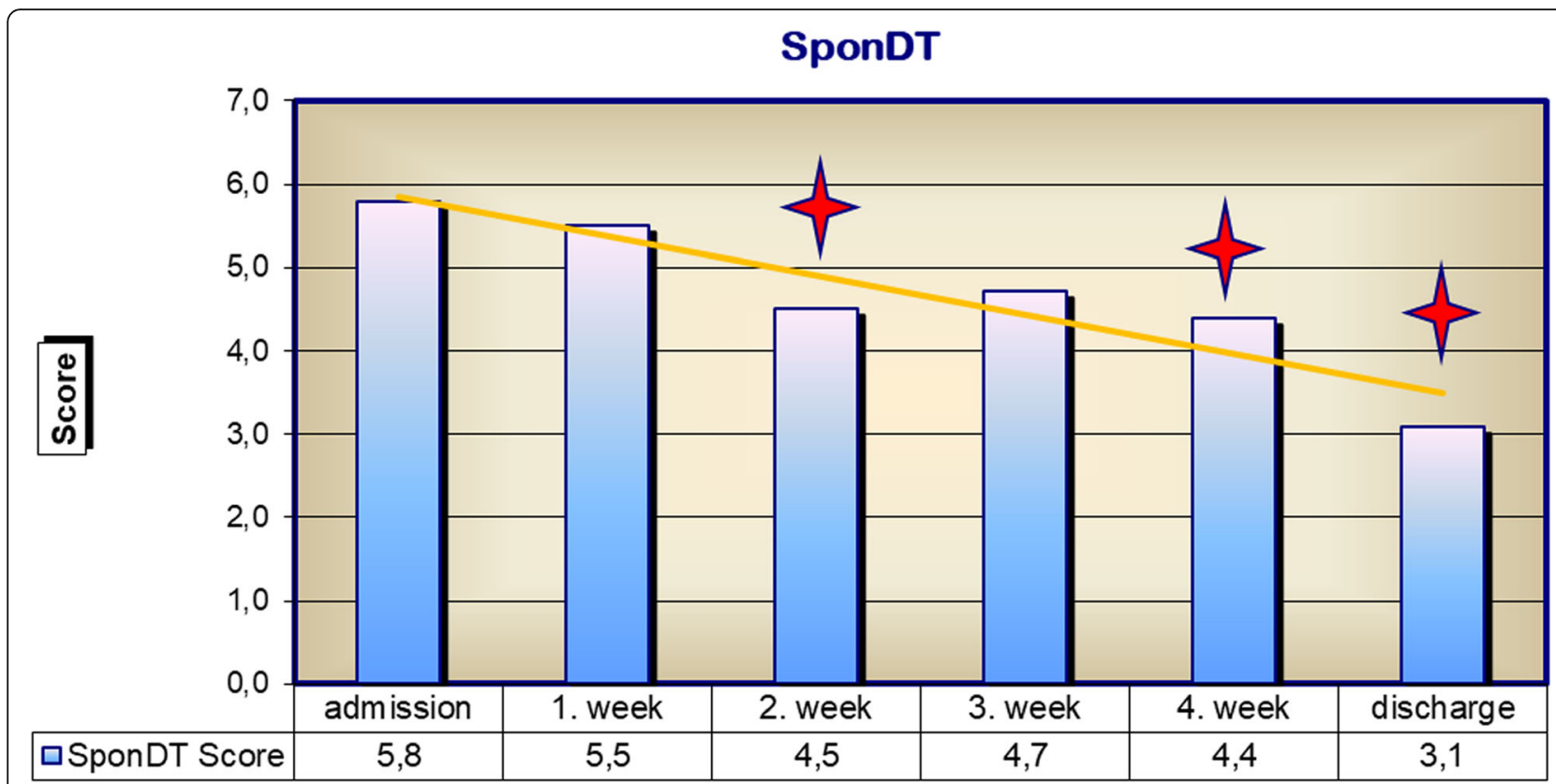

Fig. 6 SponDT recording at admission to hospital and during the course of treatment; ${ }^{*} p<0.05$

optimization of treatment remain in the scientific focus and form the basis of stage-appropriate spondylodiscitis therapy by means of classification [31,32].

Likewise, in the field of surgical therapy, minimally invasive and gentle surgical procedures are the focus of scientific consideration. The minimally invasive thoracic approach of the spine and the implantation of PEEK or titanium cages avoid the use of bone graft [33, 34].

MRI and laboratory inflammatory markers are essential to this scoring system. While the latter retain their diagnostic importance in monitoring the course of treatment of spinal osteomyelitis, the use of MRI is not justified in cases of spondylodiscitis arising from surgical treatment of the spinal region; rather, clinicians should resort to the use of CT for monitoring the progression of spondylodiscitis. We stress that subjective pain perception is an integral and important parameter of SponDT for treatment evaluation. SponDT can be used in both the initial diagnosis of spondylodiscitis and in disease progression during treatment.

\section{Abbreviations}

CRP: C-reactive protein; NRS: Numeric rating scale; MRI: Magnetic resonance imaging; CT: Computer tomography; ASA: American Society of Anesthesiologists; NIDDM: Non-insulin dependent diabetes mellitus; IDDM: Insulin dependent diabetes mellitus; SSC: Spondylodiscitis severity code; SponDT: Spondylodiscitis Diagnosis and Treatment
Funding

The authors certify that they have NO funding for the research.

Availability of data and materials

Not applicable

\section{Authors' contributions}

LH conceived the study, participated in its design and coordination and helped to draft the manuscript. NH participated in the design of the study and performed the statistical analysis. DM carried out the clinical examinations and performed the statistical analysis. $\mathrm{GOH}$ helped to draft the manuscript. All authors read and approved the final manuscript.

\section{Authors' information}

Not applicable

\section{Ethics approval and consent to participate}

Ethical approval for these studies has been granted by the University of Jena Germany. All procedures were in accordance with the ethical standards of the institutional research committee. The participants declared their consent in writing

\section{Consent for publication}

Not applicable

\section{Competing interests}

The authors declare that they have no competing interests.

\section{Publisher's Note}

Springer Nature remains neutral with regard to jurisdictional claims in published maps and institutional affiliations.

\section{Author details}

'Praxisklinik Dr. Homagk - MVZ GmbH, 06667 Weißenfels, Germany. ${ }^{2}$ Centre for Spinal Cord Injuries and Department of Orthopedics, BG Kliniken Bergmannstrost, 06112 Halle (Saale), Germany. ${ }^{3}$ Clinic of Trauma Hand- und Reconstructive Surgery, Friedrich-Schiller-University Jena, Jena, Germany.

${ }^{4}$ Praxisklinik Dr. Homagk, Markt 3, 06618 Naumburg, Germany. 
Received: 24 October 2018 Accepted: 21 March 2019

Published online: 11 April 2019

\section{References}

1. Lehner B, Akbar M, Rehnitz C, Omlor GW, Dapunt U, Burckhardt I. Standards der mikrobiologische Diagnostik der Spondylodiszitis. Orthopade. 2012;41(9): 702-10.

2. Mückley T, Kirschner M, HierholzerC HGO. Spondylitis - Spondylodiszitis: neue Therapiekonzepte. Trauma Berufskrankh. 2003:5(suppl 2):296-304.

3. Sobottke R, Seifert H, Fätkenheuer G, Schmidt M, Gossmann A, Eysel P. Current diagnosis and treatment of spondylodiscitis. Dtsch Arztebl Int. 2008; 105(10):181-7.

4. D'Agostino C, Scorzolini L, Massetti AP, Carnevalini M, d'Ettorre G, Venditti M, Vullo V, Orsi GB. A seven-year prospective study on spondylodiscitis: epidemiological and microbiological features. Infection. 2010;38(2):102-7.

5. Akbar M, Lehner B, Doustdar S, Fürstenberg CH, Hemmer S, Bruckner T, Carstens C, Wiedenhöfer B. Pyogenic spondylodiscitis of the thoracic and lumbar spine: a new classification and guide for surgical decision-making. Orthopade. 2011:40(7):614-23.

6. Bettini N, Girardo M, Dema E, Cervellati S. Evaluation of conservative treatment of non specific spondylodiscitis. Eur Spine J. 2009;18(Suppl 1): $143-50$.

7. Vos FJ, Kullberg BJ, Sturm PD, Krabbe PF, van Dijk AP, Wanten GJ, Oyen WJ, Bleeker-Rovers CP. Metastatic infectious disease and clinical outcome in Staphylococcus aureus and Streptococcus species bacteremia. Medicine. 2012:91:86-94.

8. Colmenero JD, Jiménez-Mejías ME, Sánchez-Lora FJ, Reguera JM, PalominoNicás J, Martos F, García de las Heras J, Pachón J. Pyogenic, tuberculous, and brucellar vertebral osteomyelitis: a descriptive and comparative study of 219 cases. Ann Rheum Dis. 1997:56:709-15.

9. Vorbeck F, Morscher M, Ba-Ssalamah A, Imhof H. Infektiöse Spondylitis beim Erwachsenen. Radiologe. 1996;36:795-804

10. Wikström M, Rilinger N, Vogel J, Rieber A, Diepers M, Hartwig E. Radiologische Diagnostik der infektiösen Spondylitis. Röntgenpraxis. 1996;49: 79-84.

11. Wikström M, Vogel J, Rilinger N, Diepers M, Harwig E, Rieber A. Die infektiöse Spondylitis. Radiologe. 1997:37:139-44.

12. Yilmaz U. Spondylodiscitis. Radiologe. 2011;51(9):772-8.

13. Hopkinson N, Stevenson J, Benjamin S. A case ascertainment study of septic discitis: clinical, microbiological and radiological features. Q J Med. 2001;94:465-70.

14. Maus U, Andereya S, Gravius S, Ohnsorge JA, Miltner O, Niedhart C. Procalcitonin (PCT) as diagnostic tool for the monitoring of spondylodiscitis. Z Orthop Unfall. 2009 Jan-Feb;147(1):59-64.

15. Gouliouris T, Aliyu SH, Brown NM. Spondylodiscitis: update on diagnosis and management. J Antimicrob Chemother. 2010;65:11-24.

16. Yang SC, Fu TS, Chen LH, Chen WJ, Tu YK. Identifying pathogens of spondylodiscitis: percutaneous endoscopy or CT-guided biopsy. Clin Orthop Relat Res. 2008 Dec;466(12):3086-92.

17. Fleege C, Wichelhaus TA, Rauschmann M. Systemische und lokale Antibiotikatherapie bei konservativ und operativ behandelten Spondylodiszitiden. Orthopäde. 2012:41:727-35.

18. Nolla JM, Ariza J, Gomez-Vaquero C, Fiter J, et al. Spontaneous pyogenic vertebral osteomyelitis in non-drug-users. Semin Arthritis Rheum. 2002;31: 271-8.

19. Müller EJ, Russe OJ, Muhr G. Osteomyelitis der Wirbelsäule. Orthopade. 2004:33:305-15.

20. Flamme CH, Lazoviae D, Gossé F, Rühmann O. MRI in spondylitis and spondylodiscitis. Orthopade. 2001:30(8):514-8.

21. Mörk S., Kothe R., Ulrich C. Infektionen der Wirbelsäule. Orthopädie \& Unfallchirurgie up2date 10 2011; 6: 423 - 444.

22. Guerado E, Cerván AM. Surgical treatment of spondylodiscitis. An update. Int Orthop. 2012:36(2):413-20.

23. Homagk L, Zaage J, Hofmann GO, Stuttmann R. Postoperative systemische Schmerztherapie Trauma und Berufskrankheit 2012 (12); 14 (4): 299-305.

24. Rosamond W, Flegal K, Furie K, Go A, Greenlund K, Haase N, et al. Heart disease and stroke statistics - 2008 update: a report from the American Heart Association Statistics Committee and Stroke Statistics Subcommittee. Circulation. 2008;117(4):e25-146.

25. Saklad M. Grading of patients for surgical procedure. Anesthesiology. 1941; 2(3):281-4.
26. Cramer J, Haase N, Behre I, Ostermann PAW. Spondylitis und Spondylodiszitis. Trauma und Berufskrankheit. 2003;5:336-41.

27. Akcam FZ, Kaya O, Ceylan T. Comment on: spondylodiscitis: update on diagnosis and management. J Antimicrob Chemother. 2011;66(5):1199-200 author reply 1200-2.

28. Krogsgaard MR, Wagn P, Bengtsson J.

Epidemiology of acute vertebral osteomyelitis in Denmark: 137 cases in Denmark 1978-1982, compared to cases reported to the National Patient Register 1991-1993. Acta Orthop Scand. 1998;69:513-7.

29. Jensen AG, Espersen F, Skinhøj P, Frimodt-Møller N. Bacteremic Staphylococcus aureus spondylitis. Arch Intern Med 3/1998;158(9):509-517.

30. Homagk L, Homagk N, Klauss JR, Roehl K, Hofmann GO, Marmelstein D. Spondylodiscitis severity code: scoring system for the classification and treatment of non-specific spondylodiscitis. Eur Spine J. 2016;25(4):1012-20 Epub 2015 Apr 21

31. Pola E, Taccari F, Autore G, Giovannenze F, Pambianco V, Cauda R, Maccauro G, Fantoni M. Multidisciplinary management of pyogenic spondylodiscitis: epidemiological and clinical features, prognostic factors and long-term outcomes in 207 patients. Eur Spine J. 2018;27(Suppl 2):229-36.

32. Lener S, Hartmann S, Barbagallo GMV, Certo F, Thomé C, Tschugg A. Management of spinal infection: a review of the literature. Acta Neurochir (Wien). 2018;160(3):487-96

33. Youn MS, Shin JK, Goh TS, Lee JS. Minimally invasive percutaneous endoscopic treatment for acute pyogenic spondylodiscitis following vertebroplasty. Eur Spine J. 2018:27(Suppl 3):458-64.

34. Tschöke SK, Fuchs H, Schmidt O, Gulow J, von der Hoeh NH, Heyde CE. Singlestage debridement and spinal fusion using PEEK cages through a posterior approach for eradication of lumbar pyogenic spondylodiscitis: a safe treatment strategy for a detrimental condition. Patient Saf Surg. 2015;9:35.

Ready to submit your research? Choose BMC and benefit from:

- fast, convenient online submission

- thorough peer review by experienced researchers in your field

- rapid publication on acceptance

- support for research data, including large and complex data types

- gold Open Access which fosters wider collaboration and increased citations

- maximum visibility for your research: over $100 \mathrm{M}$ website views per year

At BMC, research is always in progress.

Learn more biomedcentral.com/submissions 